\title{
Aftermath of a sea-floor eruption
}

VolCANIC eruptions on the mid-ocean ridges are thought to be the most common on Earth, yet no one has ever seen one in action. Instead we study the aftermath, the lava flows and volcanic cones and ridges built up by these eruptions, trying to deduce what happens when lava bursts forth onto the sea floor. Recent work has moved us much closer to an actual eruption, so that now the immediate consequences of deep-sea volcanism are becoming known. A great difficulty lies in identifying 10 . cations along the 75,000 $\mathbf{k m}$ of ocean ridges where eruptions are occurring this month, or will occur next year. During the past three years, new eruptions have finally been identified on the East Pacific Rise at $9^{\circ} 50^{\prime} \mathrm{N}$ and on a segment of the Juan de Fuca Ridge, at $46^{\circ} 30^{\prime} \mathrm{N}$. The first site was discovered serendipitously dur. ing dives by the submersible Alvin, apparently only days after the eruption. The second eruption was detected in progress by the United States Navy's sensitive Sound Surveillance System hydrophone array, installed during the Cold War to monitor military submarines (Eos 74, 619-620; 1993).

The photograph shows a scene from the 'tubeworm barbecue' pit on the East Pacific Rise, $9^{\circ} 50.6^{\prime} \mathrm{N}$, where the volcanic eruption killed a deep-sea hydro. thermal vent community (R. M. Haymon et al., Earth planet. Sci. Lett. 119 , 85-101; 1993). Divers in Alvin recovered scorched pieces of tubeworm and other animals in the area. Both the freshness of the tissue and dating of the new lava by ${ }^{210} \mathrm{Po}-{ }^{210} \mathrm{~Pb}$ radioactive decay indicated

that this eruption took place only $8-18$ days before divers first visited the site on 14 April 1991 (K. H. Rubin and J. D. Macdougall, Eos 72, 231; 1991). The ashy sediment was apparently created by a hydrovolcanic explosion that fragmented glassy basalt and a hydrothermal mineral deposit, together with the hap. less marine organisms.

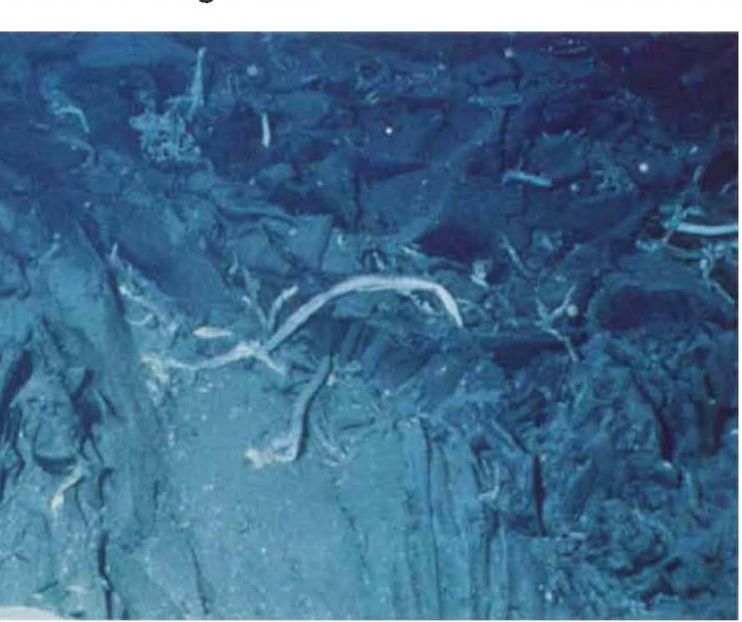

fresh, corrugated lava and some of its tubeworm victims.

the initial stages of hydrothermal vent systems (see also R. W. Embley et al., Geology 19, 771-775; 1991). At both sites, the new lava flows had voluminous, diffuse hydrothermal fluid venting directly through cracks in the basalt. The temperatures and compositions of the initial fluids at $9^{\circ} \mathrm{N}$ had unusual and extreme characteristics (high gas content, low salinity, Iow $\mathrm{pH}$ ) that pointed to vapour condensation after subsurface boiling. The biology was limited to whitish, flocculant bacterial mats, up to $5 \mathrm{~cm}$ thick. The fluid flows disrupted the mats and created a blizzard of white particles suspended in the water for tens of metres. Visits a year later saw a reduc. tion in the diffuse venting and bacterial mats, construction of vent chimneys, and colonization by 'conventional' vent organisms (R. M. Haymon et al., Eos 73, 524-526;

Both eruption sites have now been visited several times by expeditions using remote photographic, mapping and sampling instruments, seismometers and Alvin dives. The $9^{\circ} \mathrm{N}$ flow is a sheet flow extruded onto the floor of the axial summit caldera. It would have been invisible to a 'before-and-after' comparison of sea-floor maps, which have a resolution of only $10 \mathrm{~m}$. The Juan de Fuca eruption, in contrast, created an elongated pillow ridge about 20-25 m high that is clearly identifiable on new bathy. metric maps.

Although flowing red-hot lava was not observed, the expeditions did find extraordinarily fresh, glassy lava accompanied by a new type of hydrothermal activity and biology that may be unique to
1992). An Alvin expedition is now under way to check on progress.

Active eruption sites reveal critical processes that occur on short timescales, particularly the transport of magma from crustal reservoirs to the sea floor, the areal distribution of flows from a single episode, the time between episodes, and the establishment and evolution of hydrothermal circulation and its accompanying biological colonies. These colonies living in eruption zones must stay abreast of the geological changes, as we would like to do.

Jennifer Reynolds

Jennifer Reynolds is at the LamontDoherty Earth Observatory, Columbia University, Palisades, New York 10964, USA. tions display a remarkable petrological diversity, including both 'normal' (NMORB) and 'enriched' (E-MORB) varieties. The new radiometric dates seem to confirm that recent eruptions have occurred as far as $4 \mathrm{~km}$ off-axis, a distance equivalent to $60 \mathrm{kyr}$ of sea-floor spreading.

The unexpected abundance and diversity of off-axis volcanism at the AdVenture site is in marked contrast to a second well-studied site near $12^{\circ} \mathrm{N}$ (ref. 10). At this site, there is little evidence for off-axis volcanism and the spatial distribution of off-axis basalt compositions defines a number of elongated regions that extend for $15-40 \mathrm{~km}$, parallel to the spreading axis. In each such region, basalt composi- tions are consistent with derivation from a common parent magma composition, and it is believed that they represent the original petrological zoning of the East Pacific Rise axis. If so, samples in each zone should be similar in age and there should be a regular increase in age with distance off-axis. Such predictions should be readily testable by these newly refined dating techniques.

Segment-to-segment contrasts such as

1. Goldstein, S. J., Perfit, M. R., Batiza, R., Fornari, D. J.\& Murrell. M. T. Nature 367, 157-159 (1994)

. Batiza. R. Duncan, R. A. \& Janecky, D. Dating Young MORB, Workshop Rep. (JOi inc. Washington DC, 1988)

Rubin, K. H. \& Macdougall, J. D. Earth planet. Sci. Lett. 101. 313-322 (1990).

. Goldstein, S. J., Murrefl, M. T. \& Williams, R. W. Earth planet. Sci. Lett. 115. 151-159 (1993). these illustrate the complexity that underlies even the East Pacific Rise, arguably one of the Earth's simpler volcanic systems, and emphasize the continuing need for precise and accurate age determinations.

David M. Christie is in the College of Oceanic and Atmospheric Sciences, Oregon State University, Convallis, Oregon 97331, USA.

\footnotetext{
5. Volpe, A. M. \& Goldstein, S. J. Geochim. cosmochim. Acta 57, 1233-1241 (1993).

6. Duncan, R. A. \& Hogan, L. G. Eos 74 (suppl.) 687 (1993) 7. Haymon. R. M. et al. Eos 72, 505; 507 (1991).

8. Haymon, R. M. et al. Earth planet. Sci. Lett. 119 85-101 (1993)

9. Perfit, M. R. etal. Geology (in the press)

10. Reynolds, J. R. etal. Nature 359, 493-499 (1992).
} 